\title{
Fatima Al-Fihri Founder of the First World University
}

\author{
Fahira Fejzić-Čengić \\ Correspondence: Fahira Fejzić-Čengić, Professor, Media and Communication, University of Sarajevo, FBIH, Bosnia \\ and Hercegovina.
}

Received: Mar. 9, 2020

Accepted: Apr. 17, 2020

Online Published: June 19, 2020

doi:10.11114/smc.v8i2.4903

URL: https://doi.org/10.11114/smc.v8i2.4903

\begin{abstract}
The first modern university concept is made up of a set of simple and proven facts that are rarely studied at European Universities today, from Sarajevo to London. Simply they are just consciously suppressed. This makes the link from the mind disappeared unable to answer the question: how the mid-sluggish religious centuries-old period of Europe was awakened, stepping into a new age. Thus, the current islamophobia would be more easily overcome and people as mankind could more easily cooperate and settle in the beauty of life. Young women, and the founder Fatima Al-Fihri from the Karaouine, University in Africa, established curricula, degrees, diplomas, gown and tassels, and sent the first large volumes of translated books, scientific discoveries and insights for the establishment of early European universities such as Sorbonne, Bologna, Padua from Tunisia, Morocco, Africa, actually from the huge library of the Al Fihri University, University of Al-Karaouine. Can this truth be embedded into the curricula of modern university knowledge?
\end{abstract}

Keywords: University,knowledge, founders, middle ages, transferring knowledge in the Medieval Europe, cathedral schools, education, translating, encyclopedia, educational institutions, history of knowledge, educational process, individual,founders, Fatima al-Fihri, Univesity of Kairouan

\section{Introduction}

The text about the first university that was the forerunner of today's numerous world universities has recently reappeared again on national and regional portals. This theoretical paper introduces the notion of personal contribution, expanding the traditional paradigm of educational institutions to encompass activities for the establishment of the first university. From the pen of this year's authors, through amazing story of setting of the first University one could find out the basic facts- the model of higher education, as we consider it today, is a merit of Fatima al-Fihri an Arab woman, who established University of Al-Karaouine in Fez (Morocco).The same topic was discussed from different authors at the other portals, but there is one thing common for all of them - Guinness World Records and UNESCO ${ }^{1}$ recognised this University as the oldest existing institution with continuous education in the world. ${ }^{2}$ What is particularly interesting is the fact that the founder of the university was a young woman, Fatima, and that this information is almost unknown in the large encyclopedias of knowledge about education, tertiary level, about universities, seems equally unknown in the curricula of the most universities in Europe today and in the world. It is especially important that this is an unknown in European universities actually created on the base of knowledge, curricula, teaching experiences, books and university forms of Fatima's University.

\section{Goals}

The purpose of this article is to emphasize that the existing data about universities are often known facts to the internal public, but unknown to the outside external public. Through the history, some of the various knowledge could not be transferred before scientists discovered them and they remind unknown to the rest of the world and educational public. It is the fact refracting, in its own way, between the internal and external public. A good example should be a well known fact about hieroglyphics. Without deciphering papyrus and the efforts of several scholars it would be remain unknown what they actually meant. This is also an attempt to get to know more about the first founder of the university within the categorization of the earliest well known centers of education. The paper aims to represent the personality of Fatima al Fihri and try to set up her work at the proper place of founders of modern college education.

\footnotetext{
1 "Medina of Fez". UNESCO. Retrieved 31 July 2012.

2 https://voxfeminae.net/strasne-zene/fatima-al-fihri-osnivacica-prvog-svjetskog-sveucilista/
} 
The current research about the first university is focused on the records found in the 'Encyclopedia Britannica', the three 'Encyclopedias of Islam', 'The Muslim Heritage of Our World', 'The Encyclopedia of Islam', The Encyclopedia of the World Atlas' and some other history books and articles.

The analysis considers existing researches about one little known but constituting university in Fez-which history showing deep movability of human knowledge from Africa to Europe, from Asia to America and opposite, because people have been accumulating knowledge throughout their history and spread knowledge that in every way moves their sines and cosines for the better

Previous great knowledge that China, Japan, Persia, have had, was moved and spread, talking about times of classics, which were fundamentally different, completely different from today, when young people accepting knowledge and learning now have everything on their cell phones..Knowledge is succulent. The best parts were kept and transferred through the best individuals, but the journey was usually slow. The role of University of Kairouan, Fez, Morocco, should not to be neglected at all. Beside, famous scientists, they are just educated there, for example Papa Gerber of Avuergne was a student at the university of Fes, and became Pope Silvester II. Or establishing of science of sociology, father of sociology Ibn Haldun was also educated at the same university.

Secondly, to show through the available literature that records about the founder of the first university are not recognized in a proper way.

Concerning genders the goal is also to remove already ingrained opinion that women were spent time in the house as housewives only and this is a small contribution to show that educated women with missions were existing and removed themselves into the whole of human society.

\section{A Classical Muslim Fall After Classical Arise}

The decadent phase Muslim nations the of the world fallen into simply does not give them the opportunity and legitimacy to identify and take pride in this fact, to build a house of education, quality education, recognition and originality which had not been missing almost thirteen centuries ago. Famous writer and historian Shekib Arslan wrote: "Qairowan, Fez, Tlemcan, Morocco and other cities of Africa had attained such heights of splendor and magnificence that no nation of modern Europe can challenge or refute their claims." ${ }^{33}$ As it is mentioned above, existing research is mostly based on the records from Encyclopedia. As a serious sources were taken the 'Encyclopedia Britannica', the three 'Encyclopedias of Islam', 'The Muslim Heritage of Our World', 'The Encyclopedia of Islam', The Encyclopedia of the World Atlas' and some other history books and articles. This penultimate encyclopedia stands out, it is the encyclopedia 'Muslim Heritage in Our World' (second edition), ${ }^{4}$ which notes the fact, among rare book sources, that Muslim education offered to Central Europe the cognition that much was learnt from their translations long before the twelfth century. In the five hundred and five years in a developed and advanced Muslim country on the ground of Europe, in Spain, in Andalusia, almost all of their ancient opus of knowledge was translated by Arabic-Hellenic scholars and translators into Arabic and then from Arabic to Latin when European countries downloaded to their languages, the initial historical prolegomena for the development of knowledge and education in the way we know it today was placed.

The center of research was the city of Toledo with a particularly strong section of 'translation knowledge'. Until then, European education was mostly related to the study of biblical knowledge, within church circles and it was only related to the needs of church organization. Other knowledge, such as rational, experimental and scientific in that period, was considered as a heresy. It is therefore important that the Arab mediation between the already gone civilization of Greece and Rome, of the ancient period in general and of what will develop on European soil later to this day, is irreplaceably important. Arabic translation has de facto threw up 'rational scholasticism' in Europe, an oncoming humanism and renaissance, experiment, surgery, microscope and scientific alphabet, which is an indispensable basic layer of the modern house of knowledge. This is where search and apprenticeship is most important from Ibn Sina or Ibn Rushd or as European languages call them-Avicena and Averroes who would be at the end of the long path and dissemination of knowledge in the West, considered as a continuation of Aristotle and Plato and Neoplatonism, first in the early universities of Paris, Padua and Bologna. The forerunner of the universities in these three cities and then in the rest will be the so-called 'cathedral schools' and monasteries formed by the end of the twelfth century and they will absorb a significant portion of the sciences, research, books brought to them by Arab researchers and translators. In this regard, the famous historian Philip Hitty in 'History of the Arabs' will say: 'No people in the Middle Ages contributed that much to human progress as Arabs and Arab-speaking nations'. ${ }^{5}$ Nerkez Smailagić explains in a coherent and powerful work

\footnotetext{
3 Amir Shakib Arslan; Our Decline Its Causes and Remedies; Rashid Rida (foreword) Islamic Book Trust (2004) pp 114. Binding: Paperback New Revised Edition, Paperback, 172 pages ISBN: 9839154540

4 The editorial staff is Ali T.S: Al Hasan, Elizabeth Wroden and Rablah Saron, and this issue appeared in 2007 in London

5 Filip Hiti, 'History of the Arabs', Publisher Veselin Masleša, 1967, Sarajevo, page 22. (Philip Khuri Hitti: History of the Arabs) Further this author, which is valuable for this topic, writes:' Arabic language during the centuries in the Middle Ages was the
} 
'The Classical Culture of Islam' how knowledge was shifted, moved, merged, dissolved, wasting away... recalls that after the collapse of ancient universities, academies and schools and the knowledge from their treasuries, extensions could be found in the East, in the age of the ruler of Husref the First, for example, who loved the Greco-Roman sciences and founded a school in the city of Jundishapur, a copy of the Alexandrian one, as a system of education. The bearers of advanced thought at that time were Nestorians and monophysites, Paul the Persian translates and interprets Aristotle, a similar school was founded in Rajshahar. In Syria, Aristotle is interpreted through Nicholas of Damascus, where early Muslim perceptions of ancient philosophy and thought would arise. John of Mount Athos interprets Greek science in a monastery in Edessa in the 7th century. For a long time, these are not the western monasteries, but precisely the Middle Eastern and Near Eastern monasteries like Mar Matal, Tur Abdin, Kenesrin where similar centers of apprenticeship flourish. ${ }^{6}$ Then, in the golden age of the great Khalifa of Abbas Harun Al-Rashid in Baghdad, the first more systematic translation centers and acquaintance of Muslim intellectuals with Greek-Hellenistic knowledge would grow up. In Damask Islam has encountered Christian theology; encounters Greek philosophy in Baghdad. In his Fihrist, Al-Nadim brings to us how the Ma'mun (Khalifa) in his dream saw a noble old man - it was Aristotle - who asked him to translate his works into Arabic.

It was the starting point of a great translation movement that put the great philosophical works of Greek antiquity into the hands of the Arabs'. ${ }^{7}$

It is this first modern precursor to the Al-Karaouine University or Fez University that is part of those paths and flows that the Higher Power has shifted knowledge, apprenticeships, scholarships, and offered the best juices of thinking, learning, ethics, aesthetics where it was most needed. For as long as knowledge is ethically deposited and segmented, while morally raising individuals and communities, it plays one of the most monumental roles of the Enlightenment, enlightenment and elevation of man and society. Protected from arrogance, protected from the ideology of power and bare power, enlightened knowledge is the correlative and base of social achievement and a happy life. On the opposite, it is on the way to fire and embrace on rubble of human stumbling all stumbling errors, we also ascribe to a man of great knowledge and little morality. As it has always been. These simple and proven facts are rarely studied at European universities today, from Sarajevo to London. There is simply a missing link to answer the question of how the mid-sluggish religious centuries-old period of Europe was awaken and stepping into a new age. In doing so, no one should be underestimated and glorify themselves, because simply the world of extremes is not an accurate interpretation. This would make today's islamophobia more easily overcome, and people as mankind would more easily cooperate and settle in the beauty of life. In the media, there is often the focus on the strange and the bizarre that only serve to 'confirm' stereotypes. Examples are the execution of a princess, terrorist acts and the oppression of women. The media tend to portray Islam as oppressive (hence women in hijab) ${ }^{8}$ (Alatas, 2006).

Apart from what will be said about Fatima Al-Fihri and her university, it is important to recall that early Sorbonne, as well as Bologna and Padua, the first large amount of translated books, scientific discoveries and insights got through Tunisia, Morocco, Africa, from the huge library of Al-Fihri University, 'Al-Karaouine' University. These books were a living book treasure from the Latin and Greek language, medicine, astronomy, rhetoric, chemistry and mathematics... Al-Karaouine University, Fatima's University, to name it, already has a library of tens and hundreds of thousands of books in all fields of apprenticeship. The first study of Muslim medicine was already being studied in southern France in the city of Montpellier in 1137. Not before, but in the Middle and Near East there are largely representative hospitals, sanatoriums, spas. Earlier, with books from the same source, the 'cathedral school' in Paris at the Church of Notre Dame

language of culture and science and the advanced thoughts of the entire civilized world. Between the ninth and eleventh centuries, more works were written in Arabic than in any other language in the fields of philosophy, medicine, history, religion, astronomy, geography. The languages of Western Europe still bear the stamp of his influence in numerous borrowings from him. His letter, just behind Latin, is the most widely used in the world. They are used by Persian, Afghan, Urdu, as a large number of Turkish, Berber and Malayan languages. Page 22.

6 The entire introductory consideration of the Classical Culture of Islam by Nerkez Smailagaic is devoted to this transfer of knowledge from continent to continent, and the sanctifying dimension of the knowledge that good and humble thinkers, dedicated and not at all arrogant, are those who have transmitted the scent of knowledge, thinking, scholarship from Asia to Europe with books. from Europe to Asia and Africa and again in the opposite direction. Only our modern science, with a dose of arrogance and imagination and endless shallowness, considers itself to be the beginning and end of knowledge and existence, of the world and of consciousness ... 43-85. sides

7 For more details on these encounters, see Nerkez Smailagić in the cult book in two volumes, 'The Classical Culture of Islam', 140-181 pages. In doing so, the author highly ranks this fact, or these facts, substantiating it by three egid that the classical culture of Islam was most influenced by the general cultural climate, fiqh schools and translations from Greek...see more in 'Classical Culture of Islam', Book I, Theology, Philosophy, Science published in Zagreb in 1973, Print 'Zrinski' Čakovec

8 Alatas, S. F. (2006), "From Jami'ah to University: Multiculturalism and Christian-Muslim Dialogue", Current Sociology, 54 (1): $112-132[123-4]$ 
began in 1170, first as translation studies and then as centers for the study of textile science and profession, mathematics ... Only then when Paris already began to stagnate, Oxford is opened in 1167.

A woman about whom all the universities of the world should know every biographical information, attitudes and achievements has long been under the veil of oblivion. She was born in the ninth century, in 841, and established the 'Al-Karaouine' complex in 859. Among the courses taught at her university are the indispensable studies of astronomy, the Qur'anic sciences, theology, law, rhetoric, writing, logic, arithmetic, geography, medicine, geography, grammar, the history of Islam, and generally history, chemistry, mathematics. ${ }^{9}$ Fatima al Fihri was a Muslim woman born in a family of merchants, who valued women's education. Although much of the information about her early life has been lost, Fatima and her sister Mariam ${ }^{10}$ are known to have been educated and devotedly religious. Another source "Encyclopedia of Islam" by Ciril Glas, at the same place where is describing city of Fez, says that the city was founded as a royal city or former capital of Morocco, from the Merin Dynasty in 1196-1549 or 592-956 by hijra. The city was founded by Mevla Idris II in 809 or 193 after being hidden, and grew with the arrival of Andalusian immigrants, which the Reconquista expelled in the famous crusades against the Muslims of Spain, under Queen Isabel and King Henry. There are probably a few of those who would have thought that their persecution would shine with the light of university and knowledge, but in times of hardship, almost no one can predict what will be born of it. That is why history is a teacher of life, though we rarely address it honestly. So first, refugees from Cordoba formed the Andalusian Quarter, a neighborhood of the same name 'Al-Karaouine'. Exactly then when Fez became the center of culture, education and knowledge Fatima Al Fihri would build its University. In addition to the University, a large mosque 'Karaouine' was built there, of the same name as the university. This mosque is still one of the largest in the world because of its holding capacity accommodating about 10,000 worshipers. The foundation-vakuf of the mosque is thought to have been prepared and left by her sister Mariam. 'In the early ninth century, along with many other Arabs, during a period of difficult migration, the Al-Fihri family left Tunisia and emigrated to Fez searching for better opportunities. Fes was considered a hectic, cosmopolitan metropolis by then standards. It is also called the "Muslim West", where art and science flourish alongside religious tradition.

Although the first years in the new city were difficult, Fatima's father, Muhammad, became a successful merchant and left a great legacy for his daughters after his death. ${ }^{11}$ Noting the growing lack of space in mosques due to the arrival of a refugee from Islamic Spain, Al-Fihri and her sister decide to invest inherited money in something useful for their local community. The sisters are beginning to build a space that will be able to accommodate everyone, both immigrants and local population. Mariam devoted herself to the construction of the Andalusian mosque, while Fatima Al-Fihri has something even bigger planned.

\section{Establishment of the First University}

Emphasizing need for further education, in 859 AD, Fatima al-Fihri founded the mosque and the 'Al-Karaouine' University, named after her hometown. The building was 30 meters long, had an internal courtyard, a courtyard, a masjid, a very spacious library and school premises, and Fatima managed all the details of the construction.

During two years of building this excellent building, in the spirit of Ramadan tradition, Al-Fihri fasted until the completion of the project and the establishment of an educational center. This can be rarely found in sources, but it is an integral part of sincere personalities who consider their accomplishments to be an expression of the High Will so the modesty must be at the first place.

The concept of the university as we know today, is exactly the result of the work of Fatima Al-Fihri. The oldest European institutions, such as the University of Bologna (founded in 1088) and the University of Oxford (founded around 1096), were inspired by Al-Fihri's idea of higher education dating back to 859. Al-Karaouine University was a pioneer in the awarding of various degrees, wearing a rigid cap and academic uniform, oral defense presentation and many other higher education related practices. Religious and Qur'anic courses were first held at the university. A kind of dedicated mekteb. Later, the curriculum was expanded with the introduction of Arabic grammar, mathematics, music, medicine and astronomy and soon began to award degrees to their graduates and seniors. During medieval times, the university was considered aa a great intellectual center. Al-Karaouine is becoming a renowned spiritual and educational center visited by intellectuals and scholars from all over the world. In these mosaic-decorated halls, early algebra was invented. Pope Sylvester II. for the first time learned Arabic numbers and brought them into Europe. Many scholars have disseminated the knowledge acquired at Al-Karaouine throughout the Western world, paving the way for the

\footnotetext{
9 We found these significant details in 'Muslim Heritage in Our World', second edition, page 318, London 2007, published by Foundation for Science Technology and Civilization, London

$10 \mathrm{https} / /$ voxfeminae.net/strasne-zene/fatima-al-fihri-osnivacica-prvog-svjetskog-sveucilista/

11 Ibidem
} 
European Renaissance period. The revolutionary education that made it possible for many did not want to miss Al-Fihri herself, who also became a student of the school and attended various classes until her late years. Her diploma, carved in wood panel, is still on display at the University Library today.

University Library is one of the oldest libraries in the world and contains over 4000 different manuscripts. Among them is a copy of the Qur'an from the ninth century written in Kufa script on the skin of a camel, as well as an Arabic version of the Gospel from the 12th century. The library was recently renovated under the direction of architect Aziza Chaouni. ${ }^{12}$

After Al-Fihri death, the University continued to operate. The mosque has become the largest in Africa with the capacity to accommodate 22,000 people. Al-Karaouine University was formally incorporated into the university system of higher education in Morocco, most recently, in 1963 and is still strong today. The doors of the University remain open to the public by offering education to women and men from all parts of the world. One of the former students is Fatima al-Kabbaj, who later became the only female member of the Moroccan Supreme Council of Religious Knowledge.

\section{She Laid the Foundation Stone}

It is impossible to remain immune to the power and vision of Fatima Al-Fihri, a woman who succeeded in founding the first world's university in the 9th century, which was open to all people, of all ages, social classes and religions. Her vision of society and her innovative approach of thinking about ways in which education can be transformed, paved the way for all later universities all over the world. No less valuable is work of her Sister Mariam. Therefore, it should be emphasized that together they were builders, visionaries, smart and courageous women. The sisters Fatima and Mariam al-Fihri, were then highly educated women from a famous merchant's family, came to Fez from Qirwan, that is, Kairouan, today's Tunisia. That is why the university is named as the city from which the al-Fihri family came. ${ }^{13}$ After the death of his father, who was a respected and wealthy merchant, and then his wife and other brothers, Fatima and Mariam inherited enormous wealth and wanted to do something to achieve the good of this and future world, something that would serve the community in this world, and in the future to acquire an even greater good, which brings with it a foundation/vakuf. The university founded by Fatima al-Fihri in the following period was under the patronage of the Sultans and various alternating dynasties. In the period from 13th to $14^{\text {th }}$ Century, during the reign of the Marinid Dynasty, university possessed a rich collection of manuscripts and books, as it is Al-Muvatta of Imam Malik, written on gazelle leather parchments, 'Sirra' by Ibn Ishak, then an original transcript of Ibn Haldun's work by Al-'Ibar and many others. The famous XII-century cartographer Muhammad al-Idrisi lived in Fez, so it is assumed that he was also one of the lecturers at this university, and some historians state that Gerber of Auvergne (Auvergne, a province in France) was also educated there at a prestigious and widely known university, later Gerber of Avuergne became Pope Silvester II. Nicolas Cleynaerts, a sixteenth-century Flemish grammarian, and seventeenth-century Dutch orientalist and mathematician Jacob Van Gool were also educated at that university.

From well-known Muslim scholars, University Al-Karaouine has introduced well-known, student or teaching names, such as Ibn Rushayd al-Sabti (died 1321), Muhammed Ibn al-Hajj al-Abdari al-Fasi (died 1336)a scholar of the Maliki mezheb and an accomplished theologian, Abu Imran Yaqub al-Fasi (died 1039) a Maliki scholar of Sufi provenance, Joannes Leo Africanus (d. 1554), a famous travel writer and geographer, Muhammed al-Idrisi (d. 1240)cartographer, geographer and Egyptologist, Abu Bakr ibn al-Arabi (d. 1148), a Maliki lawyer, Qur'anic and Hadith commentator, Lisan ad-Din ibn al-Khatib (d. 1374), poet, writer, historian, physicist, politician, and later governor of Granada, Nur ad-Din al-Bitruji (d. 1204)world-renowned astronomer and caddy, Sidi Ali ibn Harzihim (d. 1163), the great Sufi scholar and promoter of the Gazali teaching in that part of the Muslim world, and at the end the most remarkable name of this university Ibn Khaldun (d. 1406), "father" of sociology, historiographer, economist, demographer. Also, although the woman founded and funded this, the oldest university in the world, women acquired their right to education at University Al-Karaouine only in the mid-20th century. Whether women have had the right to education at this institution in the previous centuries or in the period after the university was founded is a current historical unknown, which would certainly be interesting to explore that in the future. ${ }^{14}$

It is interesting that, the Encyclopedia Britanica mentions early antiquity universities such as the Socrates of Greece and Aristotle in scientific units on the history of the university...then early Indian universities are mentioned, and moves on to Bologna University as the oldest one. Along with Bologna, the ancient Egyptian Al Azhar University is mentioned, but certainly is not mentioned, in any way, really the oldest Muslim university. Following universities as mentioned as

\footnotetext{
$12 \mathrm{https}$ //voxfeminae.net/strasne-zene/fatima-al-fihri-osnivacica-prvog-svjetskog-sveucilista

${ }^{13} \mathrm{https}$ //www.dialogos.ba/2016/03/08/muslimanka-fatima-al-fihri-osnovala-je-najstariji-univerzitet-na-svijetu/

14 https://www.dialogos.ba/2016/03/08/muslimanka-fatima-al-fihri-osnovala-je-najstariji-univerzitet-na-svijetu/
} 
early ones: Oxford 1249, Balliol 1263, Merton 1264, Exeter 1314, Oriel 1326, Quennes 1340. There is even a detail that Oxford only accepts male students until 1878 when women started studying too. There is no mention of Fatima AlFihri and her approach to the university, where both boys and girls studied, including herself. There were then prominent universities in Vienna from 1365, in Heidelberg from 1386, in Cologne in 1388, in Leipzig in 1409, in Andrews, Scotland in 1410, and in Copenhagen, Denmark in $1479 \ldots{ }^{15}$ Only this small reflection on the tightness and incompleteness of the inscription of one of the most famous encyclopedias of knowledge as we modern people and intellectuals observe, confirms the arrogance and incompleteness of our so incomplete knowledge and apprenticeship and the role of ideology and tightness we have with us, even we write references in such an encyclopedia itself. Finally, let's look back at an important thread that is the theoretical background of all this particular layer in this essay, the knowledge is universal, general, the beyond, descended to man of reason and heart to share and recognize, to expand, not to plagiarize, and to reduce his egoism wherever he can and as much as he can.

\section{Conclusion}

The paper concludes that of Fatima al-Fihri, was the founder of the first university although unrecognized in current times. Bearing in mind that she lived in the ninth century, her contribution and charismatic personality, deserved a special attention showing the need for further systematic comparative research to better understanding of the phenomenon of educational process in the current environment. From the historical viewpoint, in those times when Fatima al Fihri lived, it can be confirmed, once more, that the knowledge has a common value, and not only in Antics or later when Timbuktu was recognized as the university, though it was not unlike today's universities.

It is important to emphasize that verily we can also find traces of the tower of Babylon, symbol of misunderstanding. It is still existing as well as paradigm through the history when the knowledge was transferred by ships carrying books. Victory of Babylon tower is also reflected through Arabic language which was a link or language matrix to Europe. Fatima al-Fihri sent the first large volumes of translated books, scientific discoveries and insights from Africa, University of Karaouine, to famouus European universities. The catch is that we constantly use to revise, but this might be a kind of re-conceptualization which could explain precise influences of individuals, founders of modern college education. Above mentioned facts, opening a field for a new point of view to the education and knowledge making a base for the answer from the beginning of the article: the truth about Fatima al-Fihri, her life and work, deserved to be embedded into the curricula of modern university knowledge.

\section{Acknowledgement}

I would like to thank mr. Senella Krehic-Fočak, for her technical assistance and for supporting of the ideas presented here.

\section{References}

Alatas, S. F. (2006). From Jami'ah to University: Multiculturalism and Christian-Muslim Dialogue. Current Sociology, 54(1), 112-132. https://doi.org/10.1177/0011392106058837

Amir, S. A. (2003). Our Decline Its Causes and Remedies; Rashid Rida (foreword) Islamic Book Trust (2004) 148 Binding: Paperback New Revised Edition, Paperback, 172 pages ISBN: 9839154540 Atlas islamskog svijeta, Udruženje ilmije BiH, Sarajevo, 2003.

Encyclopedic World Atlas, Country by country (1998). Philip's, The Royal Geographical Society, London

Habermas, J. (2006). Political communication in a media society: Does democracy still enjoy an epistemic dimension? The impact of normative theory on empirical research. Communication Theory, 16(4), 411-426. https://doi.org/10.1111/j.1468-2885.2006.00280.x

Hiti, F. (1967). 'Istorija Arapa', Editor: 'Veselin Masleša', Sarajevo, 1967.

'Muslim Heritage in Our World', second edition, p. 318, London 2007. godine, Editor: Foundation for Science Technology and Civilisation, London

Philip, K. H. (2002). History of the Arabs, Revised: 10th Edition, Palgrave Macmillan; (September 6, 2002) ISBN 0-333-63142-0

Smailagić, N. (1976). Klasična kultura islama II (Classical Culture of Islam II), Zagreb, 1976. 55.

Smailagić, N. (1973). 'Classical Culture of Islam', Book I, Theology, Philosophy, Science published in Zagreb 1973, Print 'Zrinski' Čakovec

15 The World Book Encyclopedia, World Book International, World Book Inc., London, Sidney, Tunbridge Wels, Chicago, 1992. 1993., 1994. ISBN 0-7166-6694-4, stranice 266-271 
The World Book Encyklopedia (1994). World Book International, London, Sydney, Tunbridge Wells, Chicago, Volume U-V 20

\section{Copyrights}

Copyright for this article is retained by the author(s), with first publication rights granted to the journal.

This is an open-access article distributed under the terms and conditions of the Creative Commons Attribution license which permits unrestricted use, distribution, and reproduction in any medium, provided the original work is properly cited. 